\title{
40. THE OCCURRENCE OF BOLBOFORMA, A PROBABLE ALGAL CYST, IN THE ANTARCTIC MIOCENE OF DSDP LEG 35
}

\author{
F. Rögl, Department of Geology, Museum of Natural History, Vienna, Austria \\ and \\ P. Hochuli, Department of Geology, Swiss Federal Institute of Technology, Zurich, Switzerland
}

\section{INTRODUCTION}

Site 325 was drilled on the continental rise of the Bellingshausen Sea $\left(65^{\circ} 2.79^{\prime} \mathrm{S} ; 7^{\circ} 40.40^{\prime} \mathrm{W}\right)$ during DSDP Leg 35 , the third cruise into Antarctic waters. A single hole was drilled in 3745 meters of water which penetrated 718 meters of sediment. Terrigenous sediments of gray and greenish clay, silty claystone, silts, and sandstones characterize the early Miocene to Pleistocene deposits. The hole bottomed in lithified sandstones and conglomerates.

The Pleistocene to late Miocene sediments yielded primarily well-preserved siliceous fossils; however, a sparse fauna of planktonic foraminifera, characteristic of high latitudes, was found in the uppermost PliocenePleistocene part of the hole. A fauna of arenaceous benthonic foraminifera accompanied by a few calcareous specimens occurs beginning in Core 7 (moving downhole), at about 520 meters subbottom. One sample $(325-10-1,94-96 \mathrm{~cm})$ at 709.5 meters contains the planktonic foraminiferal species Globorotalia zealandica incognita indicating that it is in the foraminiferal Zone N 6 to $\mathrm{N} 7$ (early Miocene).

Within this section containing calcareous fossils, individuals of the fossil group Bolboforma were found at 615.3 meters $(325-8-2,133-135 \mathrm{~cm})$. The genus Bolbofor$m a$ has been described from the Oligocene and Miocene of northern Germany (Daniels and Spiegler, 1974) and the systematic position of this taxon is discussed below. The occurrence of Bolboforma at Site 325 in the early Miocene sediments, as determined by planktonic foraminifera, is in agreement with its occurrence in northern Germany. Bolboforma appears to be a fossil group with significant stratigraphic value.

The depositional environment of this part of the section at Site 325 was middle to lower bathyal. The dominance of more primitive genera of arenaceous foraminifera and the occurrence of deep water calcareous benthonic species indicate water depths of 23000 meters. Bolboforma is believed to be of planktonic origin.

\section{LITHOLOGIC AND PALEONTOLOGIC COMPOSITION OF THE SEDIMENTS}

Bolboforma was found only in Sample 325-8-2, 133$135 \mathrm{~cm}$ in the DSDP material. Lithologically the sample is a light gray silty claystone with burrow structures. The washed residue contained a rich fauna of arenaceous benthonic foraminifera, some calcareous benthonic foraminifera, as well as a few planktonic forms. These foraminifera were accompanied by numerous radiolarians and, in the 63 to $177 \mu \mathrm{m}$ fraction, by several different species of Bolboforma. In the fine fraction (44-63 $\mu \mathrm{m})$ there were only detrital minerals, radiolarians, and a few small foraminifera. Bolboforma was not found in the fraction finer than $63 \mu \mathrm{m}$, and it was also lacking in most of the coarser fraction.

The following species of arenaceous foraminifera were found in the sample: Ammobaculites agglutinans, Ammolagena clavata, Bathysiphon sp., Bolivinopsis cf. cubensis, Cribrostomoides crassimargo, C. subglobosus, Cyclammina incisa, Eggerella bradyi, E. propinqua, Haplophragmoides carinatus, $H$. quadratus, $H$. cf. scitulum, Martinotiella communis, Psammosphaera fusca, Pseudobolivina antarctica, Recurvoides contortus, Reophax spp., $R$. nodulosus, $R$. pilulifer, $R$. sabulosus, ?Reophax difflugiformis, Rhabdammina abyssorum, $R$. linearis, Rhizammina algaeformis, Saccammina placenta.

The calcareous foraminifera were less abundant and included: Cibicidoides pseudoungerianus, Dentalina havanensis, Fissurina orbignyana, Gyroidina planulata, Lagena spp., Laticarinina pauperata, Lenticulina convergens, Nonion sp., Nonionella sp., Pyro murrhina Quinqueloculina sp., Qu. collumnosa. A few specimens of planktonic foraminifera, including Globigerina sp., Globorotalia ex gr. peripheroronda were also found. The preservation of the material was good. The calcareous foraminifera showed almost no traces of dissolution and the radiolarians were recrystallized into quartz, but were not replaced by calcite.

\section{SYSTEMATIC POSITION OF BOLBOFORMA}

In their original description, Daniels and Spiegler (1974) said that the genus Bolboforma probably belonged to a group of test-forming protozoans. The authors discussed the affinities between this genus and Testacea, Tintinnina, and the calcareous algae. Consequently, it is possible that Bolboforma and the Calcisphaerulidae belong to related fossil groups. In contrast to Bolboforma, all Protozoa which form calcareous tests construct the chamber walls with tiny crystals, or platelets. The wall structure in foraminifera is formed by a more or less regular arrangement of these small elements (Hemleben, 1969). In radiate, calcareous foraminifera, the wall comprises several different lamellae and is thickened by the addition of secreted carbonate layers (Hansen and Reiss, 1971; Bé and Hemleben, 1969). The foraminiferal genus most closely related to Bolboforma is Lagena. Lagena belongs to the Rotaliina, a group characterized by a perforated wall and which commonly exhibits a radial wall structure.

The wall of Bolboforma consists of a single layer of calcite which is optically a single crystal, without any traces of growth lines or separated elements (Plate 2, 
Figures 5, 6); perforations are also lacking. The sectioned specimens show only the cleavage planes of calcite. Recrystallization probably did not occur as there is no evidence of a connection between the wall and the test infilling. The wall structure is the same regardless of whether the infilling is sediment or secondary calcite. The only growth pattern is seen at the surface of the wall which is scaly or granulated (Plate 2, Figures 4, 7, 8). The ornamentation of Bolboforma is variable, exhibiting numerous modifications ranging from sharp ridges to spines to knobs and/or smooth surfaces. There is, however, no difference in the wall structure. The wall and all the processes and ornamentations are formed by the same single calcite crystal.

These structures show that the test of Bolboforma is formed by a different process than forms the walls of protozoans. Consequently, a comparison with similar tests of algae is made. Algae which live in a singlechambered test are mostly planktonic fresh water forms. The Chrysomonadineae have organic and siliceous walls and some species of the Phacotaceae (Chlorophyceae) have organic tests incrusted by calcium carbonate. These tests, however, normally consist of two valves. Another group of flagellates living in tests are the Euglenophyceae; however, in this group the wall is formed by organic material and all tests formed by flagellates are very small-normally less than $20 \mu \mathrm{m}$.

Comparable forms are only the cysts of protozoans or algae. Encystments occur in different groups either as a regular stage in the ontogenetic cycle or as a resting stage as a protective function against changes in the environment. As far as is known, only organic cysts are formed as resting stages of protozoans. There are two groups among the algae which form anorganic encystments, Dinophyceae and Chrysophyceae. Although the Dinophyceae or dinoflagellates normally form organic cysts a few species of Peridiniaceae and the fossil family Calciodinelliaceae produce calcareous encystments. These cysts are characterized by girdle and tabulation, and an organic inner membrane (Wall and Dale, 1968; Wall et al., 1970). No organic inner membrane was found in Bolboforma after processing by acids.

Siliceous and calcareous encystments occur in the Chrysomonadales. In this group the Archaeomonadaceae occur in marine sediments and have siliceous cysts which are very similar in outline to Bolboforma. However, they measure only $5-30 \mu \mathrm{m}$ in diameter. The Recent group, Ochromonadaceae, which lives in fresh water, also produces similar siliceous forms.

The Coccolithineae, which also belong to the Chrysomonadales, have calcifications in the motile and nonmotile phase (Parke and Adams, 1960). These tests and cysts formed by these organisms each consist of a large number of small elements.

The fossil group Calcisphaerulidae, which probably belongs to the cyst-forming algae, possesses walls composed of small calcite crystals. Individuals of this group are normally smaller (50-60 $\mu \mathrm{m})$ but range up to $200 \mu \mathrm{m}$.

It was possible to identify the genus, Bolboforma, in the Leg 35 material, as a cystal stage of an unknown fossil group. The neck-like aperture is closed by a calcite membrane (Plate 2, Figure 1), which seals the test at a level below the beginning of the collar-like neck. This was observed to be a common feature on a large number of specimens which we viewed in transmitted light. The membrane has the same structure as the surrounding wall, and its surface shows the similar granulation. In comparison to the above-mentioned encystments, it seems to be advisable to classify Bolboforma as belonging to a hitherto unknown group of planktonic Chrysomonadales.

\section{SYSTEMATIC DESCRIPTION}

\section{Bolboforma clodiusi Daniels and Spiegler}

(Plate 1, Figures 4-6; Plate 2, Figure 3)

1922 Lagena hystrix Reuss-Clodius, p. 109.

1974 Bolboforma clodiusi n. sp.-Daniels and Spiegler, p. 63, pl. 7, fig. 4-6.

The onion-shaped test, for which the genus Bolboforma receives its name, is strongly flattened on the aboral side in Bolboforma clodiusi. The surface is covered by rounded to angular, short, stout spines. A short neck, bordered by an apertural lip protrudes from the subglobular test. The shape of this neck is extremely variable and may be a simple rounded tube which is somewhat inflated near the base to triangular in cross-section (Plate 2, Figure 3). In contrast to the original description of the species, the population investigated here is believed to be related to $B$. spinosa, as some specimens have rounded spines and flattened bases which also have indications of spines. The circular diameter of test is $170 \mu \mathrm{m}$, and the height of the ovoid, without the neck, averages $125 \mu \mathrm{m}$. Individuals of the species are fairly common in the material studied. The stratigraphic distribution of $B$. clodiusi in northern Germany is from the Hemmor Stage to the "late" Miocene; the Hemmor Stage is early Miocene (Burdigalian after Anderson, 1961 and nannoplankton Zones NN 4 to ?NN 5 after Martini and Muller, 1973).

Bolboforma spinosa Daniels and Spiegler

(Plate 1, Figures 1-3; Plate 2, Figures 2, 5, 6, 8, 9)

1974 Bolboforma spinosa n. sp.-Daniels and Spiegler, p. 67, pl. 9, fig. 3, 4.

Bolboforma spinosa has a globular, well-rounded test, covered by short, rounded spines. The investigated specimens are similar to the holotype, but do not have the numerous blunt spines as seen in the figured paratype. All intermediate stages between the globular $B$. spinosa and the flattened $B$. clodiusi were observed. There are also transitional forms to $B$. cf. rotunda, in which the spines are reduced in number and solidity. The apertural features are similar to those in $B$. clodiusi and the average test diameter is $160 \mu \mathrm{m}$. This species is the most common form in the investigated material and hundreds of specimens were found. The stratigraphic range given in the original description is late Oligocene (Chattian) to early Miocene (Vierlande Stage, corresponding to Aquitanian age after Anderson, 1961b).

Bolboforma laevis Daniels and Spiegler

(Plate 1, Figure 12; Plate 2, Figures 1, 4)

1974 Bolboforma laevis n. sp.-Daniels and Spiegler, p. 64, pl. 7, fig. 7 9 ; pl. 10, fig. 6.

Bolboforma laevis has a compressed sphaeroidal test similar to $B$. clodiusi. The surface is smooth, with a slight granulation of small pustules, which is more distinct in the apertural region (Plate 2, Figures 1 and 4). Similar ornamentation was seen on the surface of the membrane enclosing the test of the cyst (Plate 2, Figure 1). The circular equatorial diameter of the test is between 120 and $145 \mu \mathrm{m}$ and averages $135 \mu \mathrm{m}$; the height of the test, without the neck, is between 90 and $115 \mu \mathrm{m}$ and averages about $105 \mu \mathrm{m}$. Individuals of this species occurred less commonly than the other Bolboforma. The stratigraphic range in northern Germany is given as early Miocene (Hemmor Stage) to "late" Miocene.

\section{Bolboforma cf. rotunda Daniels and Spiegler}

(Plate 1, Figures 10, 11; Plate 2, Figure 7)

Specimens with rounded, globular tests in the Leg 35 material are similar in outline to $B$. rotunda. The surface, however, is distinctly different, lacking the broad, rounded knobs. The surface of the observed specimens is smooth with small knobs, resembling the reduced 
spine bases of $B$. spinosa. All transitions to the spinose forms are present. The species averages $140 \mu \mathrm{m}$ in diameter. It occurs fairly frequently in the studied material. The stratigraphic range for $B$. rotunda is the same as for B. spinosa and is late Oligocene to early Miocene.

Bolboforma sp.

(Plate 1, Figures 8, 9)

A few specimens of Bolboforma were observed which possess winglike processes. The surface of the globular test is covered by short knobs or spines which is probably an abnormal development in individuals of $B$. spinosa. Protruding appendices were also seen in individuals of $B$. irregularis, kindly provided by C.H. v. Daniels. The diameter of the test without the processes is about $150 \mu \mathrm{m}$.

\section{CORRELATION OF LEG 35 MATERIAL TO OTHER REGIONS}

The only known occurrences of Bolboforma are from the Oligocene-Miocene transgressions of the North Sea in the region of Hamburg in northern Germany (Daniels and Spiegler, 1974). Daniels and Spiegler also noted the earlier published accounts in which the genus had previously been described as Lagena. The striking change in faunal assemblages between the Vierlande and Hemmor stages, as described by these authors, is also accompanied by a different paleogeographical distribution of the faunas and is attributed to a sedimentary discordance as a result of renewed transgression between deposition of these two stages.

The material investigated from the early Miocene of the Antarctic area provides the missing link to these populations. The fauna is distinctly transitional in the composition of species and variety of forms. The spinose species Bolboforma spinosa and $B$. clodiusi both occur and are related by transitional forms. The smooth ovoid $B$. laevis is also accompanied by a globular species, here designated as $B$. cf. rotunda. The globular specimens are distinctly more common than the flattened ones.

That this population is stratigraphically transitional between that of the Vierlande and Hemmor stages is consistent with the age of Bolboforma-bearing sediments at Site 325 which were dated by means of planktonic foraminifera. In comparison, the inclusion of the nannoplankton Zone NN 4 as a part of the Hemmor Stage (Martini and Müller, 1973) indicates that the investigated sample is probably early Burdigalian or slightly older.

Bolboforma spiralis was observed in samples from the Palmer Ridge by Ms. L. Molinsky (personal communication). She also found this genus in samples from DSDP sites from the North Atlantic and from the Bay of Biscay (Leg 12). The worldwide use of this fossil group as a biostratigraphic indicator seems possible.

\section{ACKNOWLEDGMENTS}

The authors wish to express their gratitude to C.H. von Daniels (Hannover), who kindly made available material for comparison with new species of Bolboforma and for their helpful discussions of the investigated material. We wish to thank Ms. K. Perch-Nielsen and J.P. Beckmann (Geol. Dept. Zurich) and C.D.K. Cook (Bot. Garten, Zurich) for discussions on the systematical position of this fossil group, and Ms. L. Molinsky (Sudbury, Ontario) who contributed to the understanding of the distribution of Bolboforma from her unpublished data. K. Kelts (Zurich) kindly read the manuscript. The SEM micrographs and photoprints were prepared with high quality by H.E. Franz and U. Gerber from the ETH Geology Department. The investigations were supported by the Swiss National Science Foundation.

\section{REFERENCES}

Anderson, H.J., 1961a. Uber das Alter der Hemmor-Stufe: Meyniana, v. 10, p. 147-159. 1961b. Uber die Korrelation der miozänen Ablagerungen im Nordseebecken und die Benennung der Stufen: Meyniana, v. 10, p. 167-170.

Bé, A.W.H. and Hemleben, C., 1969. Calcification in a living planktonic foraminifer, Globigerinoides sacculifer (Brady): N. Jb. Geol. Paläont. Abh., v. 134, p. 221-234.

Bourrelly, P., 1957. Recherches sur les chrysophycées: morphologie, phylogenie, systématique: Th. Sci. Nat. Paris, p. 412.

Daniels, C.H.v. and Spiegler, D., 1974. Bolboforma n. gen. (Protozoa?)-eine neue stratigraphisch wichtige Gattung aus dem Oligozän/Miozän Nordwestdeutschlands: Paläont. Z., v. 48, p. 57-76.

Hansen, H.J. and Reiss, Z., 1971. Electron microscopy of Rotaliacean wall structure: Bull. Geol. Soc. Denmark, v. 20, p. $329-346$.

Hemleben, C., 1969. Ultrastrukturen bei kalkschaligen Foraminiferen: Naturwiss., v. 56, p. 534-538.

Martini, E. and Müller, C., 1973. NannoplanktonGemeinschaften im Miozän und Pliozän des Nordseebeckens: N. Jb. Geol. Paläont. Mh., Jg. 1973, p. 555-564.

Parke, M. and Adams, I., 1960. The motile (Chrystallolithus hyalinus Gaarder \& Markali) and the non-motile phase in the life history of Coccolithus pelagicus (Wallich) Schiller: J. Marine Biol. Assoc. U. K., v. 39, p. 263-274.

Wall, D. and Dale, B., 1968. Quaternary calcareous dinoflagellates (Calciodinellideae) and their natural affinities: J. Paleontol., v. 42, p. 1395-1408.

Wall, D., Guillard, R.R.L., Dale, B., and Swift, E., 1970. Calcitic resting cysts in Peridinium trochoideum (Stein) Lemmermann, an autotrophic marine dinoflagellate: Phycologia, v. 9, p. 151-156. 
PLATE 1

(Magnification $\times 298$ )

Figures 1-3 Bolboforma spinosa Daniels and Spiegler.

1. NMB-C 31031 .

2. NMB-C 31035 .

3. NMB-C 31033.

Figures 4-6 Bolboforma clodiusi Daniels and Spiegler.

4. NMB-C 31032.

5-6. NMB-C 31034.

Figure $7 \quad$ Bolboforma spinosa, sectioned specimen; interior of the test filled with secondary calcite. NMB-C 31046.

Figures 8,9 Bolboforma sp. NMB-C 31037.

Figures 10,11 Bolboforma cf. rotunda Daniels and Spiegler.

10. NMB-C 31041.

11. NMB-C 31042.

Figure 12 Bolboforma laevis Daniels and Spiegler. NMB-C 31040 . 

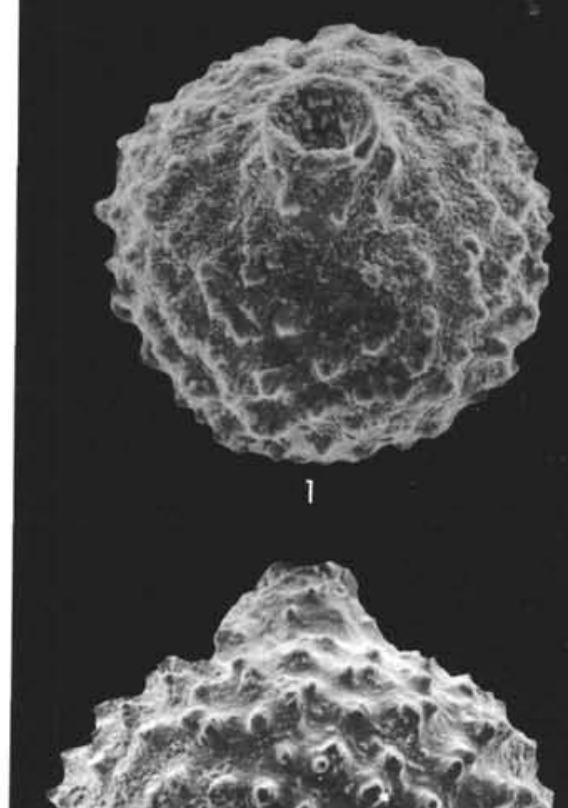

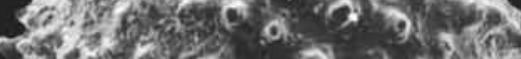

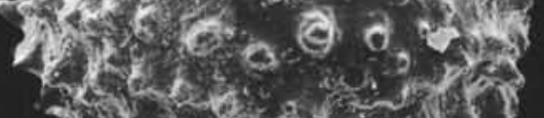
2 (5) We

$$
4
$$
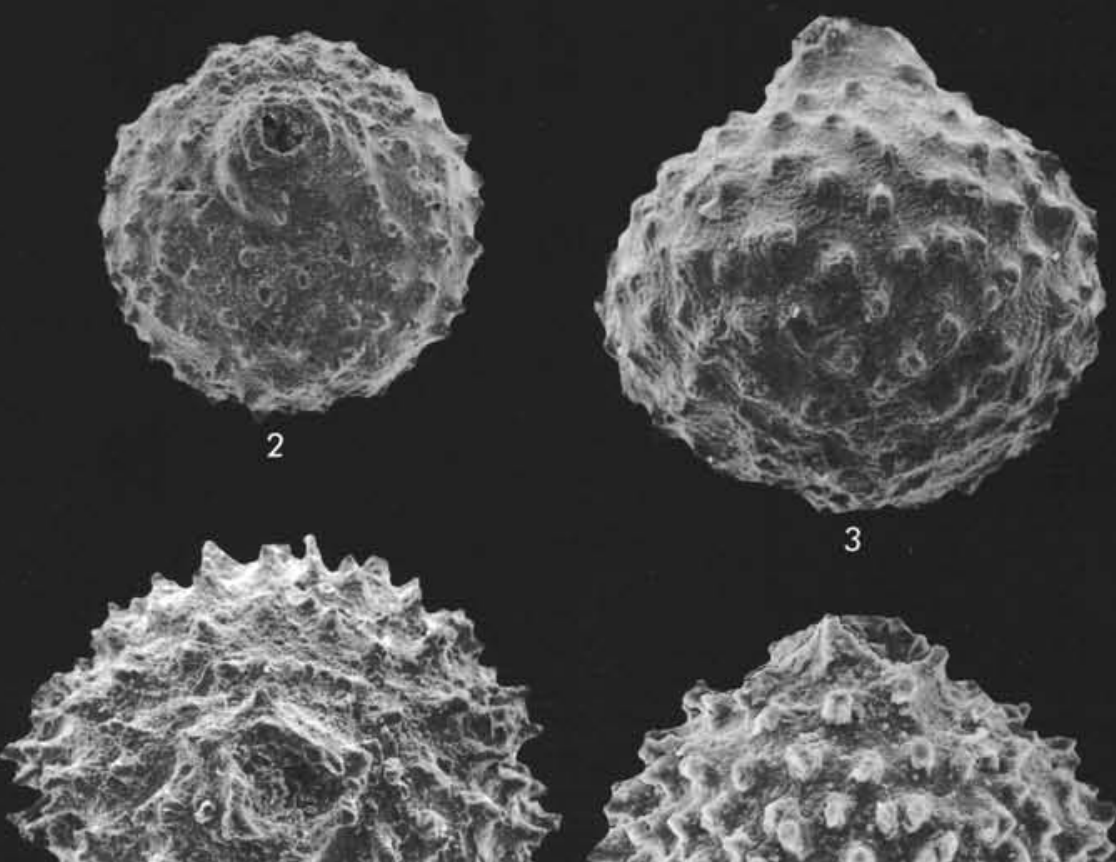

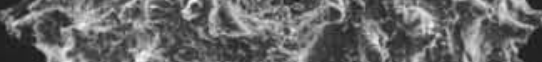

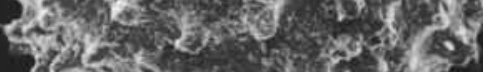

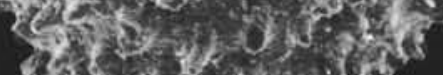

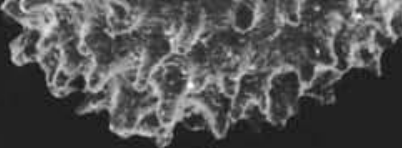

$$
5
$$

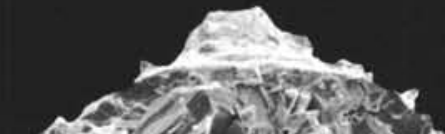

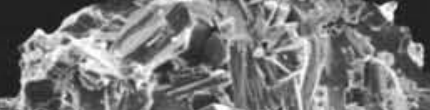

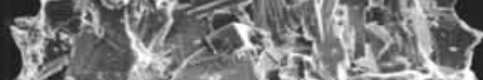

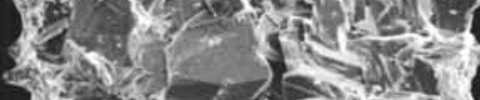

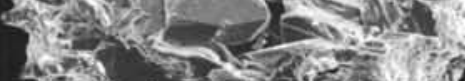

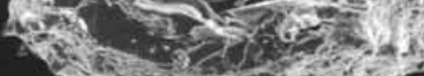
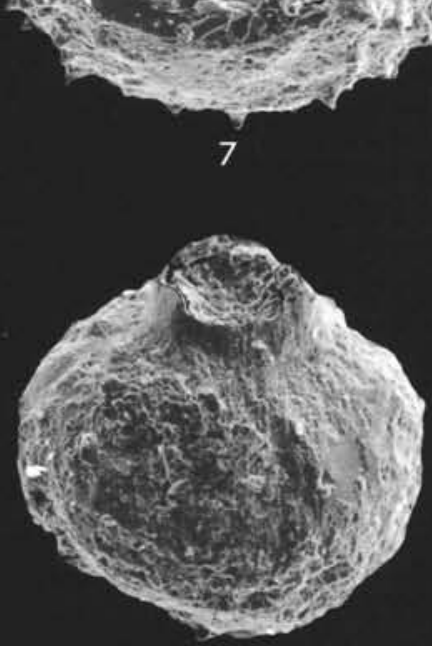

10
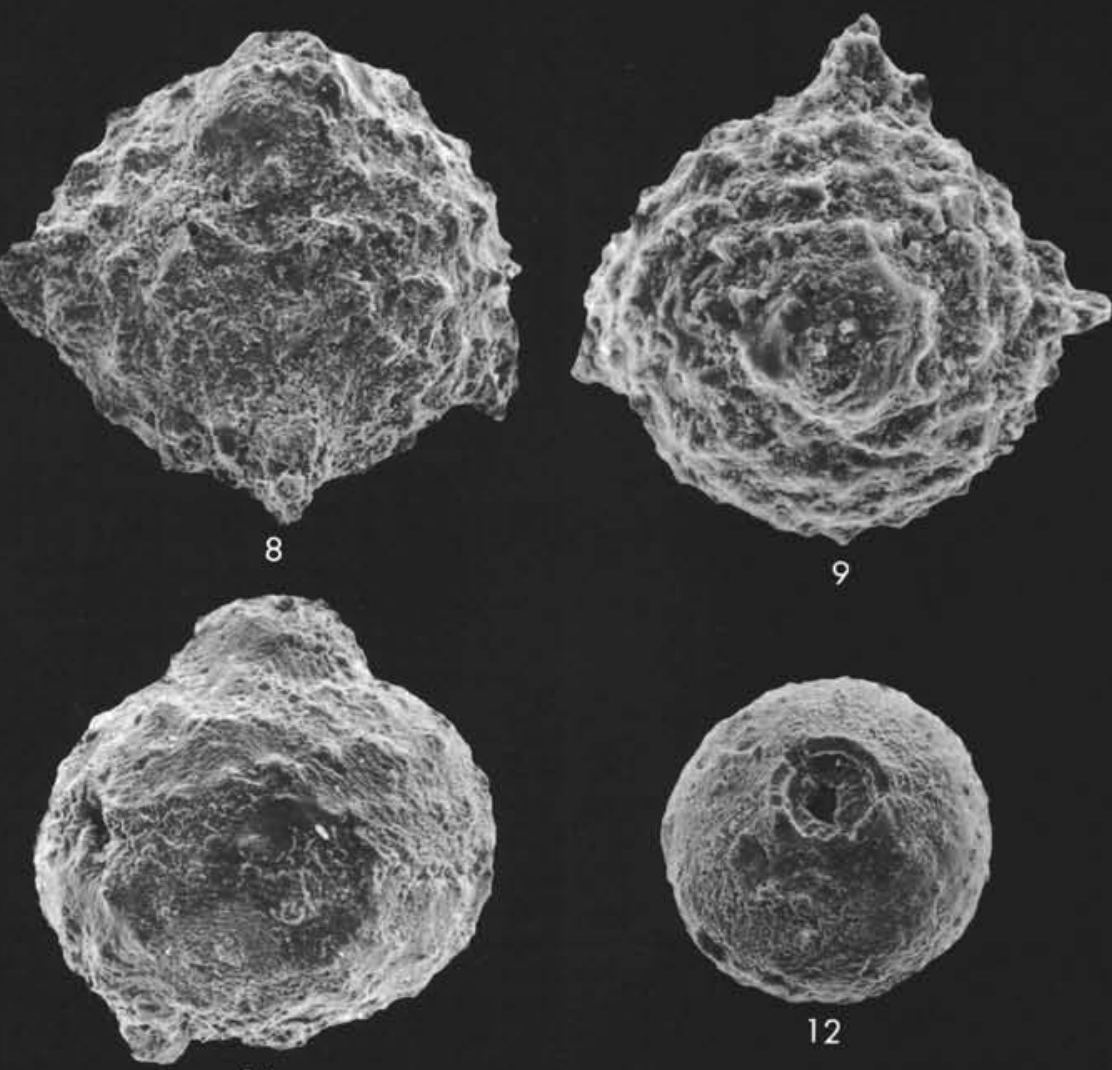


\section{PLATE 2}

Figure 1 Bolboforma laevis (see Plate 1, Figure 12). Membrane closing the apertural opening of the cyst shows the same granulation as the surrounding wall. $\times 1190$.

Figure 2 Bolboforma spinosa (see Plate 1, Figure 1). Relicts of the membrane are observed near the bottom of the apertural neck. $\times 1190$.

Figure 3 Bolboforma clodiusi (see Plate 1, Figures 5, 6). Triangular shape of the apertural neck as one of the varieties occurring within one species. $\times 590$.

Figure 4 Bolboforma laevis (see Plate 1, Figure 12). Wall surface in the apertural region covered with small pustules. $\times 1785$.

Figure $5 \quad$ Bolboforma spinosa (see Plate 1, Figure 7). The sectioned wall shows cleavages of calcite crystals; the interior of the test is filled with secondary calcite, without connection between wall and filling. $\times 1190$.

Figure 6 Bolboforma spinosa (NMB-C 31044). The sectioned wall shows no structure; the test is filled with sediment. $\times 1190$.

Figure $7 \quad$ Bolboforma cf. rotunda (see Plate 1, Figure 11). Wall surface showing small scales of calcite and coarser rugosities, resembling reduced spines. $\times 1190$.

Figure $8 \quad$ Bolboforma spinosa (see Plate 1, Figure 3). Wall surface with blunt spines and small calcite scales, which are arranged in lines, growing from the spines as a center (see lower left spine). $\times 1190$.

Figure $9 \quad$ Bolboforma spinosa (see Plate 1, Figure 2). Form of spines varies within one specimen from knobs to tips; the small openings found in this single specimen are no pores but secondarily caused perforations. $\times 1190$. 


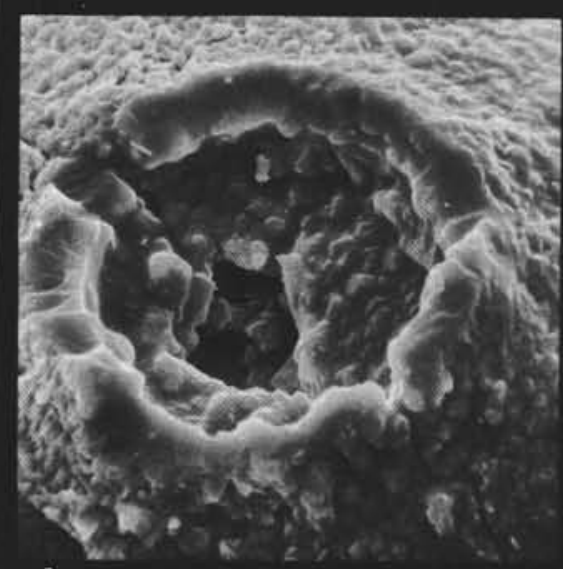

1

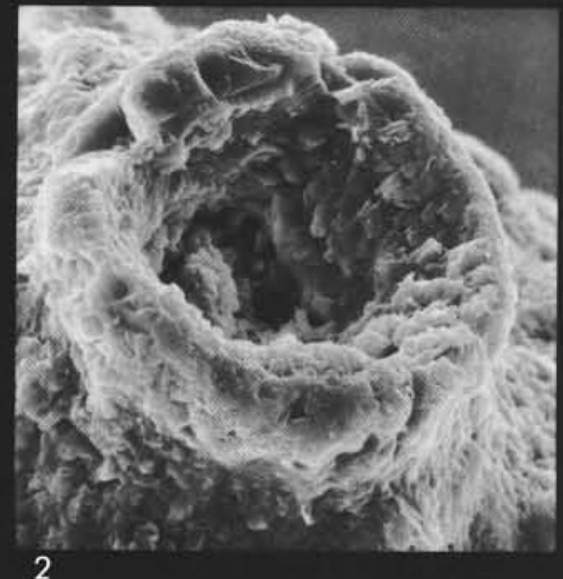

2

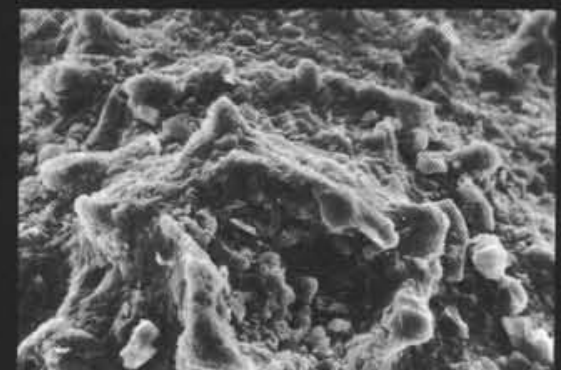

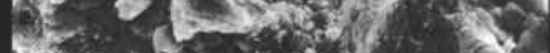

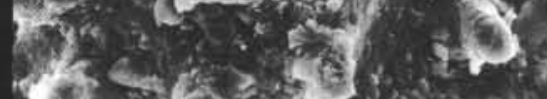
2.4
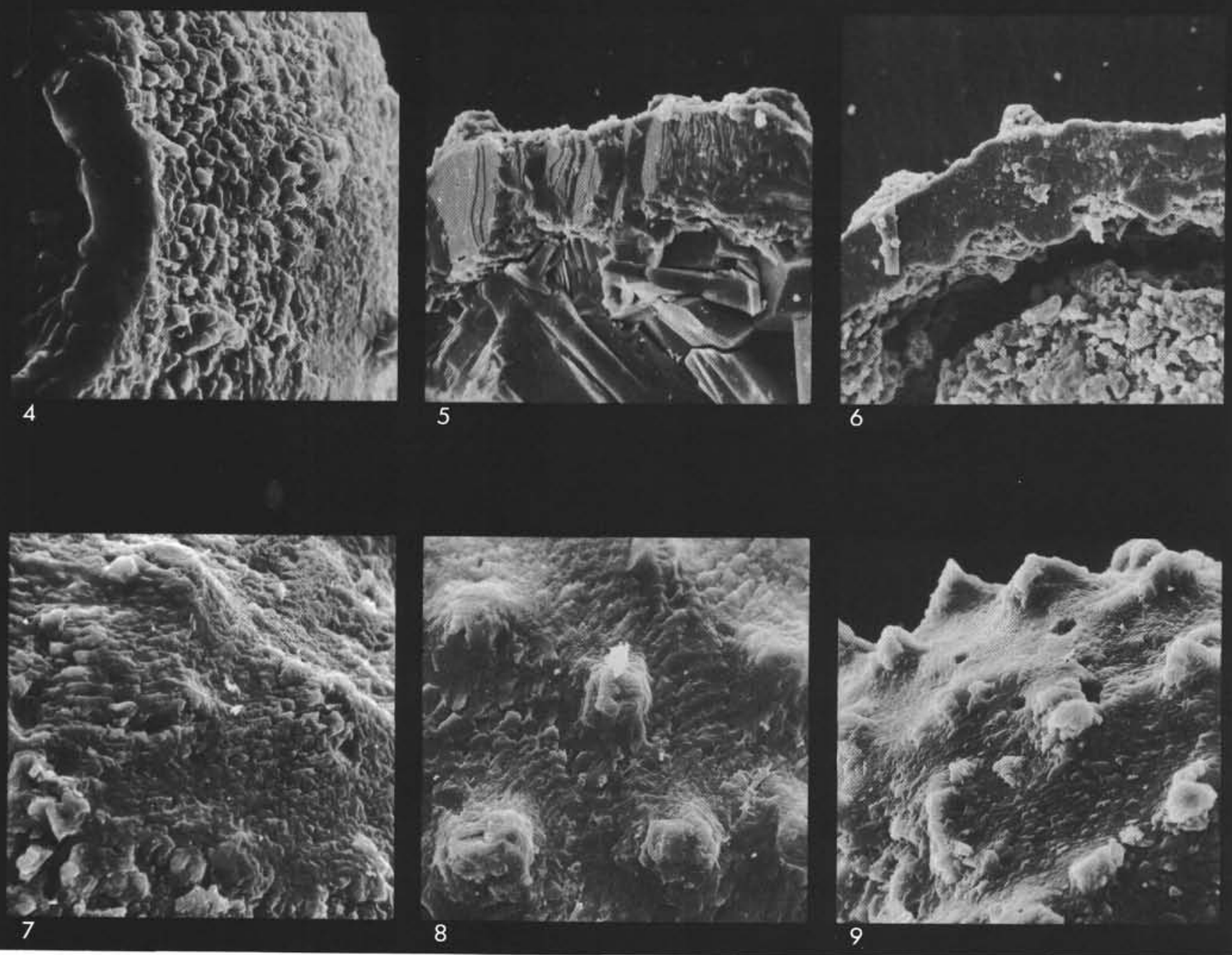